\title{
PERFORMANCE COMPARISON OF MULTICELL SERIES AND NPC MULTILEVEL CONVERTERS FOR A STATCOM
}

\begin{abstract}
In this paper, we present a comparative study of the performances of the multicells series and the Neutral-PointClamped (NPC) three-level converters used at synchronous static compensators (STATCOM) for the control of the voltage at a point of the network. The analysis consists on a mathematical modeling, a pulse width modulation (PWM) control algorithm application and a simulation using the Matlab Simulink environment. The simulation results obtained show that the STATCOM allows the regulation of the voltage at the point of common coupling (PCC) by acting the reactive energy that it can supply or absorb. References 22, tables 4, figures 24.
\end{abstract}

Key words: STATCOM, VSC, NPC converter, multicell series converter, modeling, control.

В статье представлено сравнительное исследование характеристик многоэлементных последовательных и трехуровневых преобразователей со связанной нейтральной точкой, используемых в синхронных статических компенсаторах (STATCOM) для управления напряжением в точке сети. Анализ основан на математическом моделировании, алгоритме управления с широтно-импульсной модуляцией (ШИМ) и моделировании с использованием среды Маtlab Simulink. Полученные результаты моделирования показывают, что STATCOM позволяет регулировать напряжение в точке общей связи действием реактивной энергии, которую он способен подавать или поглоцать. Библ. 22, табл. 4, рис. 24.

Ключевые слова: синхронный статический компенсатор, преобразователь источника напряжения, преобразователь со связанной нейтральной точкой, многоэлементный последовательный преобразователь, моделирование, управление.

Introduction. To improve the power quality, Flexible AC Transmission Systems (FACTS) devices have received widespread interest for high voltage power systems control. They are faster and more flexible of compared with mechanically switched control of the transmission system [1, 2]. Among the FACTs compensators that offer this possibility, the synchronous static compensators «STATCOM» are connected in parallel at sensitive points of the network. The STATCOM is the first FACTS using the Voltage Source Converter (VSC). It uses high power gate turn-off (GTO) thyristors or insulated gate bipolar transistors (IGBT). Highly efficient, this device is characterized by the robust support of the voltage in the presence of strong disturbances, the balancing of asymmetric and fluctuating loads and the damping of power oscillations [3, 4]. The design of VSC can be realized in several ways. It can be modeled using the conventional (two-level) or multilevel three-phase bridge converter. However, multi-level converter offers a wide variety of advantages over conventional converter such as lower harmonic content, reduced stress on switches and decreased switching loss [5]. Currently used STATCOM based on multilevel converters are very popular in medium-voltage networks, including flying-capacitor multilevel converters (FCMC), diode-clamped multilevel converters (DCMC) and cascaded H-bridge multilevel converters (CHMC) [6].

Cascaded H-Bridge Converters (CHBs) are the most common topologies in STATCOM applications. The advantages of CHB converters include low switching loss, modularity and lack of holding diodes. However there disadvantage resides is the fact that one cannot get a negative output voltage and an isolated power supply for each module $[7,8]$.

The Neutral-Point-Clamped (NPC) converters are the first practical topology for multi-level voltage converters. The advantage of this topology is generalizable so as to obtain a greater number of output voltage levels, all the phases are connected to the same common DC bus and the number of capacitors used is limited. The disadvantage of this structure is when the number of levels becomes high, the balance of the voltages across the capacitors quickly becomes complex to control [8-10].

The multi-cell series converters or floating capacitors is an energy conversion topology that relies on the series setting of controlled switches. The advantage of this topology is that it eliminates the problem of loopback diodes present in the topologies of multi-level NPC inverters. In addition, the voltage stresses imposed on the power components are naturally limited. Thus, by phase, only one DC source is needed. The disadvantage of this structure is that the need to balance the voltages across the floating capacitors adds complexity to the converter [11].

From the description of the different converters we can deduce that the voltage of the output is more sinusoidal and the harmonic distortion rate will be low if the number of levels is high but the structure of the converter becomes complicated. Its cost and the complexity of its order are increased its reliability is reduced.

The focus in this paper is on using the converters multi-cells and NPC three level as a shunt connected STATCOM for the regulation of the voltage profile along the line, so as to avoid fluctuations between the voltage at the source and the voltage at the load. For a DC input voltage source supplied by the charged capacitor, the converter produces a set of controllable three-phase output voltages with the frequency of the AC power system. These voltages on the alternating side of the converter are in phase with that of the network so as to exchange only the reactive energy with the latter. The value of the current and the direction of the reactive power exchanged are set by the value of the voltage of the converter. The setting principle is described in the following paragraph.

(C) S. Belakehal, A. Djellad, R. Chenni 
Description of the studied network. In this study, we used a conventional three-phase network composed of a three-phase power source that is variable in amplitude, in phase and in frequency. It supplies three-phase electric charges through a three-phase line. The diagram per phase is illustrated in Fig. 1.

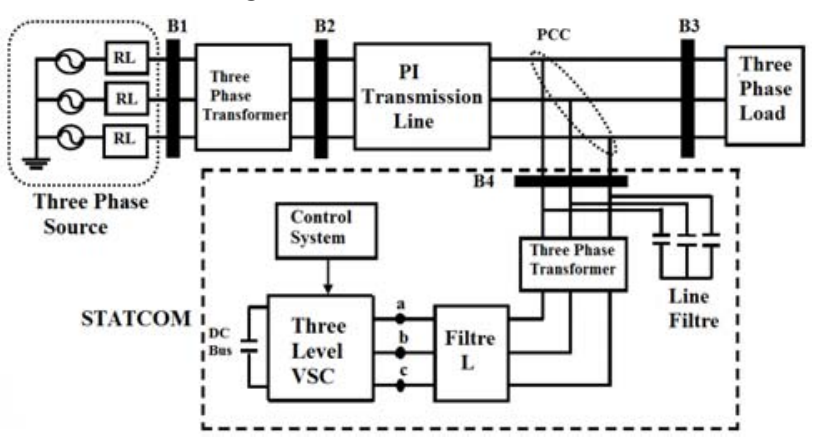

Fig. 1. Basic circuit of a STATCOM

The other major component of the system is the STATCOM which permits the regulation of the voltage at the Common Connection Point (PCC) between the network and the loads. It is composed of a continuous energy source or a capacitor associated with a static converter based on semiconductors of the IGBT type and a transformer $\mathrm{T}$ that has always a certain leakage reactance. The transformer plays a dual role: it transforms the voltage and offers the reactance required by the compensation.

The operating principle of the STATCOM is simple. By varying the magnitude of the output voltages produced, the reactive power exchange between the STATCOM and the network can be adjusted $[1,12]$

- if the amplitude of the voltage $V_{K n}(K=a, b, c)$ is greater than the amplitude of the voltage $E_{K}$, the current $I_{K}$ is advance of $\pi / 2$ on $E_{K}$ (Fig. 2,b), the compensator provides reactive power to the transmission line and the compensator behaves like a huge capacitor;

- if the amplitude of the voltage $V_{K n}$ is lower than the amplitude of the voltage $E_{K}$, the current $I_{K}$ is $\pi / 2$ behind $E_{K}$ (Fig. 2,a), the compensator absorbs reactive power at the transmission line and the compensator behaves like an immense inductor;

- if the amplitude of the voltage $V_{K n}$ is equal to the amplitude of the voltage $E_{K}$, (Fig. 2,c), the current $I_{K}$ is zero and therefore the compensation is zero.

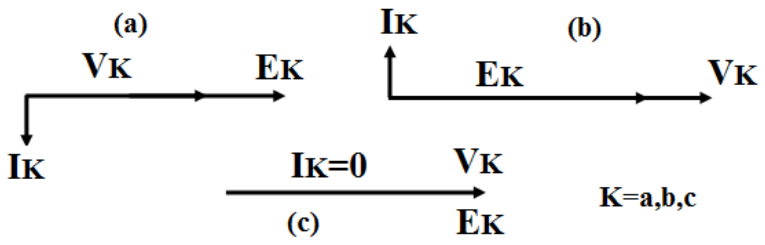

Fig. 2. STATCOM operating modes

STATCOM modeling. The equivalent circuit of the STATCOM is shown in Fig. 3. In this power system, the resistance $r$ in series with the voltage source inverter represents the sum of the transformer winding resistance losses and the inverter conduction losses. The inductance $L$ represents the leakage inductance of the transformer. In Fig. 3 the instantaneous value of system bus phase voltage are $E_{a}, E_{b}, E_{c}$, the instantaneous current the system inject into the STATCOM are $I_{a}, I_{b}, I_{c}$, the instantaneous value of converter's AC side phase voltage are $V_{a}, V_{b}, V_{c}$, the DC bus voltage is $V_{d c}$.

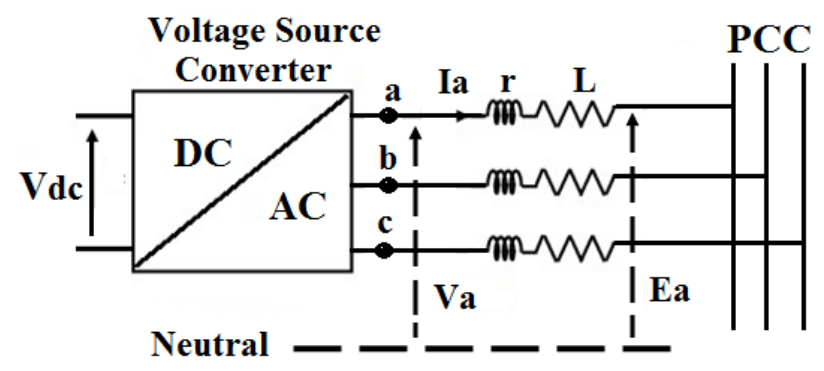

Fig. 3. Schematic diagram of the grid connection of a converter

Two Cell Converter Model. The two cells converter with three voltage levels is shown in Fig. 4. It consists of three arms, where each one consists of two cells. Each cell consists of two switches and a voltage source. The switches work in a complementary way, when one is passing the other is blocked.

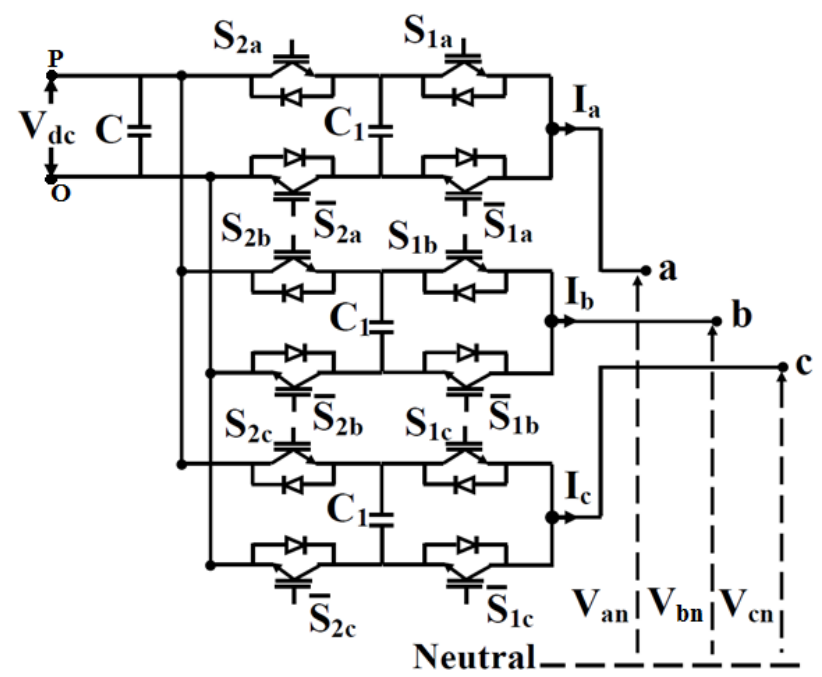

Fig. 4. Multi-cell series converter

To model the multi-cell converter, the following simplifying assumptions are used: perfect switches, perfect sources and neglected idle time $[13,15]$.

The converter is controlled by the switching functions $S_{i K}$ whose value lies be hour 0 and $1(K=a, b$ or $c$ designates the phase and $i=1$ or 2 the relevant cell) whose value lies between 0 and 1 . The Table 1 shows the different voltage levels $V_{K O}$ obtained according to the control states of the switches. Each arm can release three levels of tension.

Table 1

Switching logic and output voltage
\begin{tabular}{|c|c|c|}
\hline$S_{1 K}$ & $S_{2 K}$ & $V_{K O}$ \\
\hline 0 & 0 & 0 \\
\hline 1 & 0 & $V_{d c} / 2$ \\
\hline 0 & 1 & $V_{d c} / 2$ \\
\hline 1 & 1 & $V_{d c}$ \\
\hline
\end{tabular}

The output voltage of the converter can be expressed according to $S_{i K}$ control commands:

$$
V_{K O}=\frac{V_{d c}}{P} \times \sum_{i=1}^{p} S_{i K} .
$$


The output voltages of the converter with respect to the negative terminal (point $\mathrm{O}$ ) of the $\mathrm{DC}$ bus will be:

$$
\begin{aligned}
& V_{a O}=\frac{V_{d c}}{2}\left(S_{1 a}+S_{2 a}\right) ; \\
& V_{b O}=\frac{V_{d c}}{2}\left(S_{1 b}+S_{2 b}\right) ; \\
& V_{c O}=\frac{V_{d c}}{2}\left(S_{1 c}+S_{2 c}\right) .
\end{aligned}
$$

With O-neutral voltage $V_{O n}=-\left(V_{a O}+V_{b O}+V_{c O}\right) / 3$.

The equation which lends the voltage of the continuous node to the voltages on the alternative side $V_{a n}, V_{b n}$ and $V_{c n}$ is:

$$
\begin{aligned}
& {\left[\begin{array}{c}
V_{a n} \\
V_{b n} \\
V_{c n}
\end{array}\right]=\frac{V_{d c}}{6}\left[\begin{array}{ccc}
2 S_{1 a} & -S_{1 b} & -S_{1 c} \\
-S_{1 a} & 2 S_{1 b} & -S_{1 c} \\
-S_{1 a} & -S_{1 b} & 2 S_{1 c}
\end{array}\right]} \\
& +\frac{V_{d c}}{6}\left[\begin{array}{ccc}
2 S_{2 a} & -S_{2 b} & -S_{2 c} \\
-S_{2 a} & 2 S_{2 b} & -S_{2 c} \\
-S_{2 a} & -S_{2 b} & 2 S_{2 c}
\end{array}\right]
\end{aligned}
$$

Three-level NPC converter Model. The three-level NPC converter is shown in Fig. 5. The DC input bus is composed of two capacitors in series $\left(\mathrm{C}_{1}\right.$ and $\left.\mathrm{C}_{2}\right)$ forming a midpoint noted $(\mathrm{O})$ which allows the inverter to access an additional voltage level with respect to the conventional two levels converters. The total voltage of the DC bus is $V_{d c}$. Under normal operating conditions, it is uniformly distributed over the two capacitors which have a voltage $V_{d c} / 2$ at their terminals. Each of the three arms of the converter is composed of four controlled switches $S_{i K}(K=a, b, c$ and $i=1,2,3,4)$ and two clamped diodes connected to the midpoint of the DC bus $[10,16,17]$.

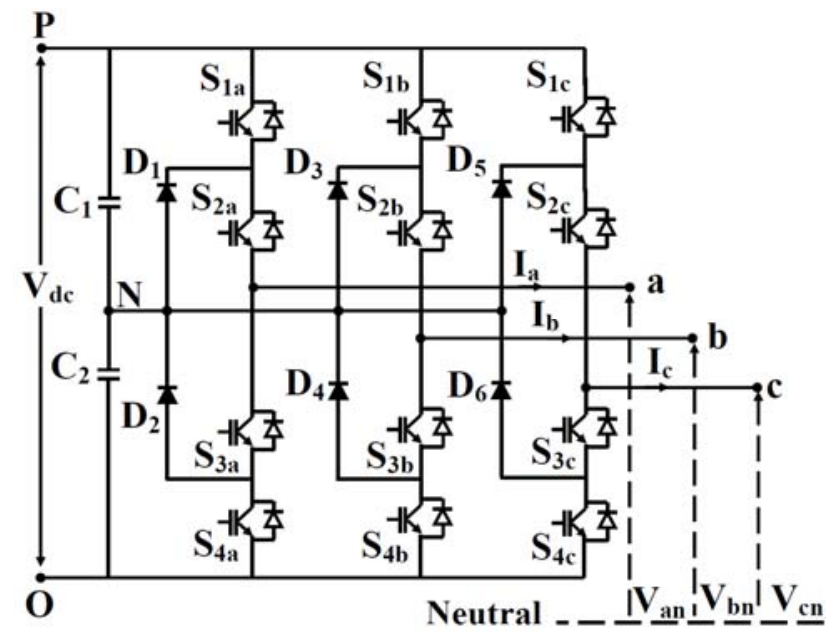

Fig. 5. Three level NPC converter

There are three possible sequences for this converter according to the different possible states for the switches (see Table 2).

Table 2

Switching logic and output voltage

\begin{tabular}{|c|c|c|c|c|}
\hline$S_{1 K}$ & $S_{2 K}$ & $S_{3 K}$ & $S_{4 K}$ & $V_{O K}$ \\
\hline 1 & 1 & 0 & 0 & $V_{d c} / 2$ \\
\hline 0 & 0 & 1 & 1 & $-V_{d c} / 2$ \\
\hline 0 & 1 & 1 & 0 & 0 \\
\hline
\end{tabular}

The objective of the modeling is to find a relation between the control variables and the electrical quantities of the alternative and continuous part of the inverter. Thus, the pairs of switches $S_{1 K}, S_{3 K}$ and $S_{2 K}, S_{4 K}$ are controlled in a complementary manner.

The following expressions shows the relationship between the voltages $V_{a O}, V_{b O}, V_{c O}$ the states of the switches and the DC voltage $V_{d c}$ :

$$
\begin{gathered}
V_{a O}=\frac{V_{d c}}{2}\left(S_{1 a}+S_{2 a}-1\right) ; \\
V_{b O}=\frac{V_{d c}}{2}\left(S_{1 b}+S_{2 b}-1\right) ; \\
V_{c O}=\frac{V_{d c}}{2}\left(S_{1 c}+S_{2 c}-1\right) .
\end{gathered}
$$

The relationships of the phase-neutral output voltages $V_{a n}, V_{b n}, V_{c n}$ of the converter according to the states of the switches $S_{i K}$ are given by the equation:

$\left[\begin{array}{c}V_{a n} \\ V_{b n} \\ V_{c n}\end{array}\right]=\frac{V_{d c}}{6}\left[\begin{array}{cccccc}2 S_{1 a} & 2 S_{2 a} & -S_{1 b} & -S_{2 b} & -S_{1 c} & -S_{2 c} \\ -S_{1 a} & -S_{2 a} & 2 S_{1 b} & 2 S_{2 b} & -S_{1 c} & -S_{2 c} \\ -S_{1 a} & -S_{2 a} & -S_{1 b} & -S_{2 b} & 2 S_{1 c} & 2 S_{2 c}\end{array}\right]$

The model of STATCOM. The dynamics equations governing the instantaneous values of the three-phase output voltages in the AC side of the STATCOM exchanged with the utility grid are given by:

$$
\begin{aligned}
& E_{a}=V_{a n}+r I_{a}+L \frac{d I_{a}}{d t} ; \\
& E_{b}=V_{b n}+r I_{b}+L \frac{d I_{b}}{d t} ; \\
& E_{c}=V_{c n}+r I_{c}+L \frac{d I_{c}}{d t} .
\end{aligned}
$$

Equations (10-12) describe the system in differential equations in $a b c$ frame. Transforming these equations to synchronous reference frame using Park's transformation the equations becomes:

$$
\begin{aligned}
& E_{d}=V_{d}+r I_{d}+L \frac{d I_{d}}{d t}-\omega L I_{q} \\
& E_{q}=V_{q}+r I_{q}+L \frac{d I_{q}}{d t}+\omega L I_{d}
\end{aligned}
$$

The instantaneous output power of STATCOM is given by:

$$
\begin{aligned}
& P=\frac{3}{2} \cdot\left(V_{d} I_{d}+V_{q} I_{q}\right) ; \\
& Q=\frac{3}{2} \cdot\left(V_{q} I_{d}-V_{d} I_{q}\right) .
\end{aligned}
$$

Within the synchronous rotating frame $V_{s}=V_{d}$ and $V_{q}=0$, the instantaneous active and reactive power is given by

$$
\begin{aligned}
& P=\frac{3}{2} \cdot V_{d} I_{d} ; \\
& Q=-\frac{3}{2} \cdot V_{d} I_{q} .
\end{aligned}
$$

STATCOM Control. The detailed control system of STATCOM is shown in Fig. 6. In this system the error signal between the rms measured and the rms AC voltage reference values is given to a $\mathrm{PI}$ regulator which produces a reference current $I_{q_{-} \text {ref. }}$. Similarly to the AC voltage regulator the error between the measured and the $\mathrm{DC}$ 
voltage reference values is given to a PI regulator that produces a reference current $I_{d_{-} \text {ref. }}$. The three-phase mains currents at the PCC are transformed into $d q$ reference frame to create, $I_{d}$ and $I_{q}$. These currents are then compared to the corresponding reference values to create error signals $\left(\Delta I_{S d}\right.$ et $\left.\Delta I_{S q}\right)$ which are transmitted to the PI controller in order to create the vectors of the reference voltages $\left(V_{\text {Sdref }}\right.$ and $\left.V_{\text {Sqref }}\right)$. Through Park's inverse transformation, the voltages $V_{S d r e f}$ and $V_{\text {Sqref }}$ are converted to $V_{\text {Saref }}, V_{\text {Sbref }}$ and $V_{\text {Scref }}$ that are required by the SPWM generator [17-19].

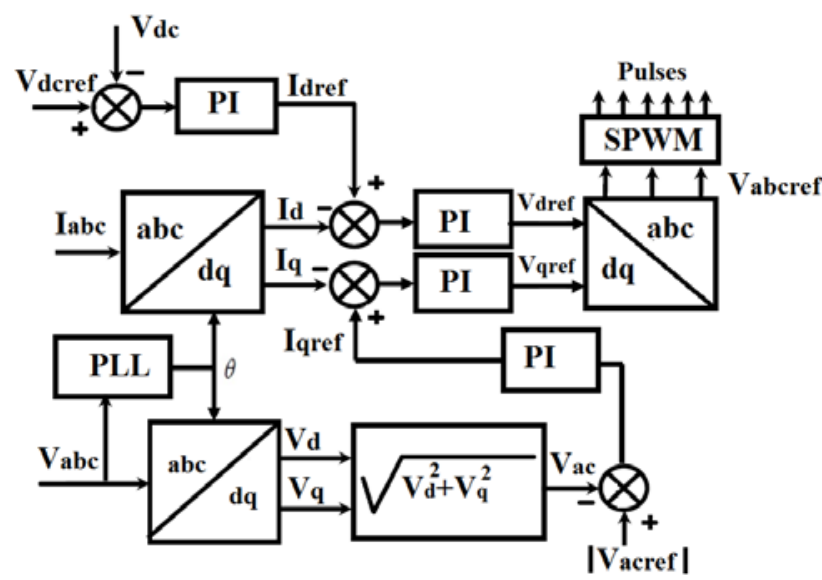

Fig. 6. STATCOM control system

The SPWM technique is one of the most popular modulation techniques applied to multi-level NPC and multi cells converters.

SPWM for two cells converters. The command of this converter is quite simple (Fig. 7). Each switching cell has its own carrier. To have a voltage of three levels, the carriers are phase shifted by $\left(\frac{2 \pi}{N-1}\right)$ and therefore by $180^{\circ}$ in this case. If these are not out of phase, the switches $S_{1 a}$ and $S_{2 a}$ or $\bar{S}_{1 a}$ and $\bar{S}_{2 a}$ switch at the same time, and the voltage is only of two levels $\left(0\right.$ and $\left.V_{d c}\right)$.

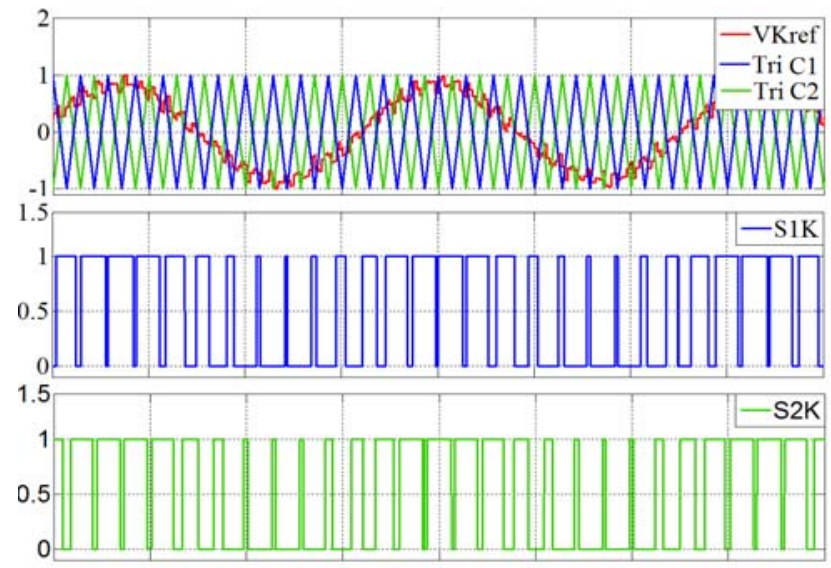

Fig. 7. Sine pulse width modulation for three two cells converter

SPWM for three level NPC converters. To generate the PWM control pulses of the three level voltage converter, two triangular carriers are required (one positive and the other negative). These carriers have the same frequency and amplitude (Fig. 8). They are then compared to the reference signal (sinus). Each comparison gives 1 if a carrier is greater than or equal to the reference, 0 otherwise. Thus for the NPC case, the control signals of the switches $S_{1 K}$ and $S_{3 K}$ are complementary and the switches $S_{2 K}$ and $S_{4 K}$ are also complementary.

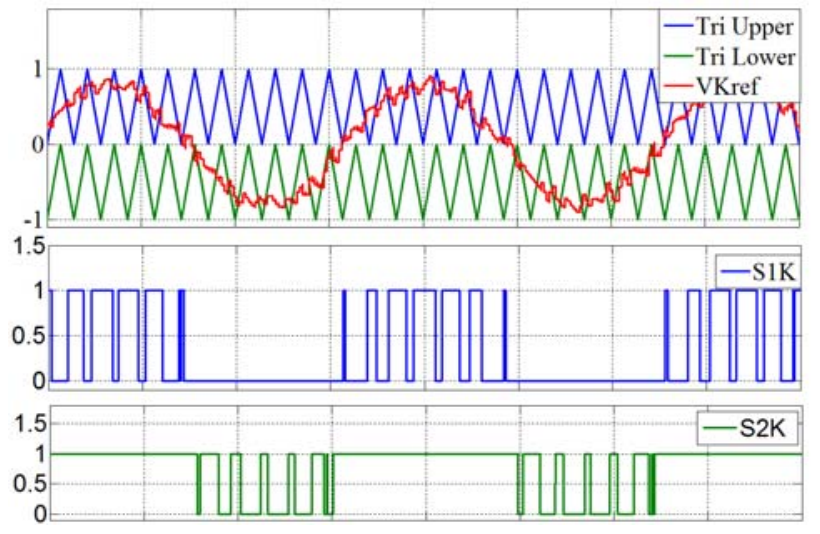

Fig. 8. Sine pulse width modulation for three level NPC converter

Simulation results. To demonstrate the efficiency of the STATCOM in the field of reactive energy compensation and voltage regulation in power grids, simulations have been carried out using Neutral-PointClamped (NPC) multilevel converters and multi-cells series based on Pulse Width Modulation Control (SPWM). For this, we applied two types of tests for the considered. The first concerns the presence of a voltage dip and a voltage drop at the source and the second the connection of additional inductive load. The entire system is simulated in MATLAB / Simulink with the parameters shown in Table 3.

Table 3

\begin{tabular}{|l|c|c|c|}
\multicolumn{4}{c}{ System parameters } \\
\hline Parameter name & Symbol & Value & Unit \\
\hline \multirow{3}{*}{ AC Source } & $U_{n}$ & 110 & $\mathrm{kV}$ \\
\cline { 2 - 4 } & $S_{n}$ & 2258 & $\mathrm{MVA}$ \\
\cline { 2 - 4 } & $f$ & 60 & $\mathrm{~Hz}$ \\
\hline \multirow{2}{*}{ Transformer } & $S_{n}$ & 40 & $\mathrm{MVA}$ \\
\cline { 2 - 4 } & $\mathrm{T} 1$ & $110 / 26.7$ & $\mathrm{kV}$ \\
\hline \multirow{4}{*}{ STATCOM } & $S$ & 3 & $\mathrm{MVAR}$ \\
\cline { 2 - 4 } & $\mathrm{T} 2$ & $27.6 / 0.6$ & $\mathrm{kV}$ \\
\cline { 2 - 4 } & $V_{a c}$ & 0.6 & $\mathrm{kV}$ \\
\cline { 2 - 4 } & $V_{d c}$ & 1.4 & $\mathrm{kV}$ \\
\hline Line & 1 & 45 & $\mathrm{~km}$ \\
\hline \multirow{2}{*}{ Load } & $R$ & 254 & $\Omega$ \\
\cline { 2 - 4 } & $L$ & 1.34 & $\mathrm{H}$ \\
\hline
\end{tabular}

Case 1. A voltage dip of $4 \%$ is applied at the threephase source during the interval $(0.15-0.25) \mathrm{s}$ and then a voltage drop of the order of $4 \%$ during the interval $(0.35$ $0.45)$ s. The Fig. 9 and 10 show respectively the threephase voltages and the rms voltage per phase at the PCC without STATCOM. The positive reaction of the STATCOM which manages to maintain the variable voltage to the PCC by controlling the quantity of reactive power injected or absorbed in the network as shown in the Fig. 11 and 12. In the interval of $t=(0.15-0.25) \mathrm{s}$ the STATCOM injects a quantity of reactive power (2.075 MVAR) to maintain voltage levels in the line in where compensator operates in the capacitive mode and in 
the interval of $t=(0.35-0.45) \mathrm{s}$ the STATCOM absorbs a quantity of reactive power (2.075 MVAR) to maintain voltage levels in the line where the compensator operates in the inductive mode (see Fig. 13). This reactive power exchange is achieved through the transformer leakage inductance which helps to smooth currents in advance or behind the angle with the primary voltages that are imposed on the secondary of the transformer by the controlled voltage source as shown in the Fig. 14. As show in Fig. 15 it is very clear that the voltage regulating loop continues to prove its effectiveness in maintaining constant voltage at the terminal of the capacitor. Figures 16 and 17 respectively show the output phase voltage of the STATCOM converter and the output line to line voltage of the STATCOM converter.

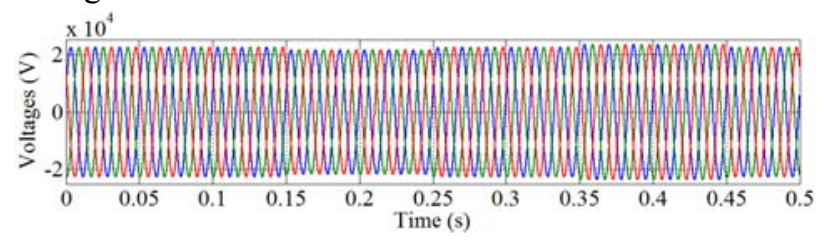

Fig. 9. Three-phase voltage $a b c$ at PCC without STATCOM
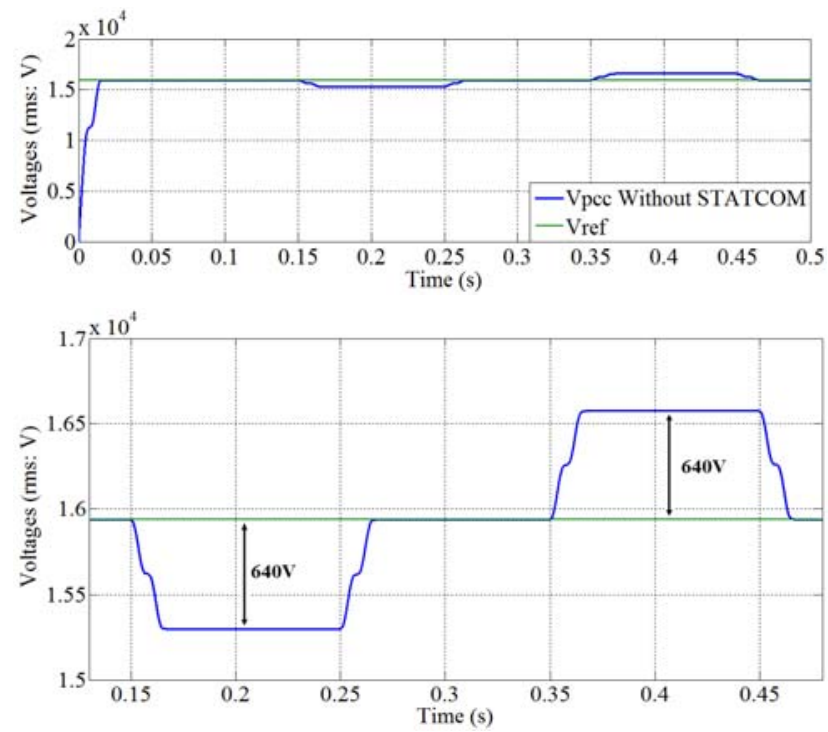

Fig. 10. Results of rms voltage phase at PCC without STATCOM
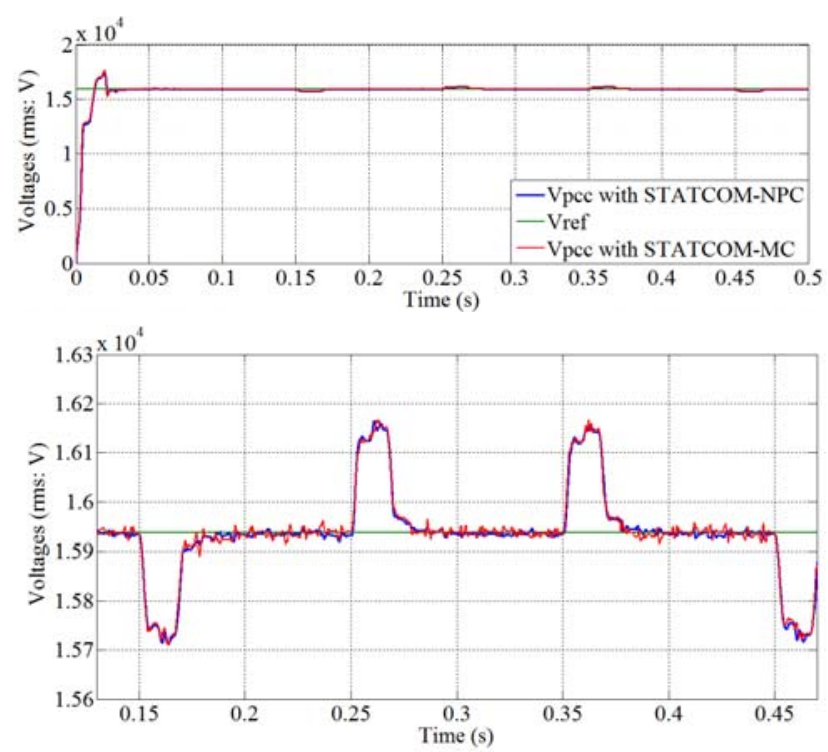

Fig. 11. Results of rms voltage phase at PCC with STATCOM

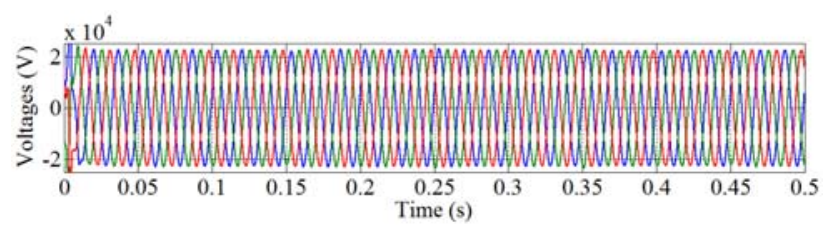

Fig. 12. Three-phase voltage $a b c$ at PCC with STATCOM

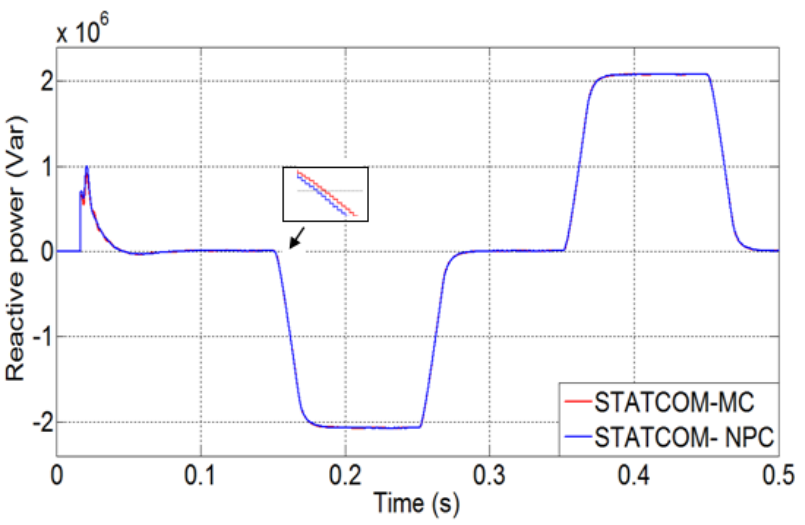

Fig. 13. Reactive power supplied and absorbed by STATCOM
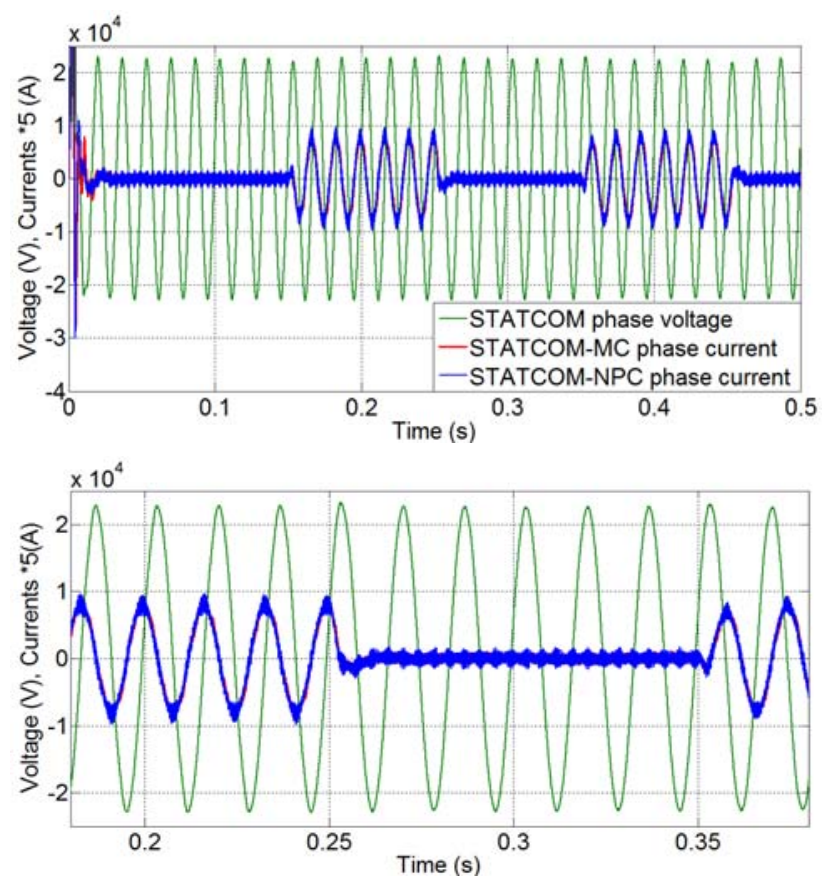

Fig. 14. Voltage and current of phase $a$ at the PCC
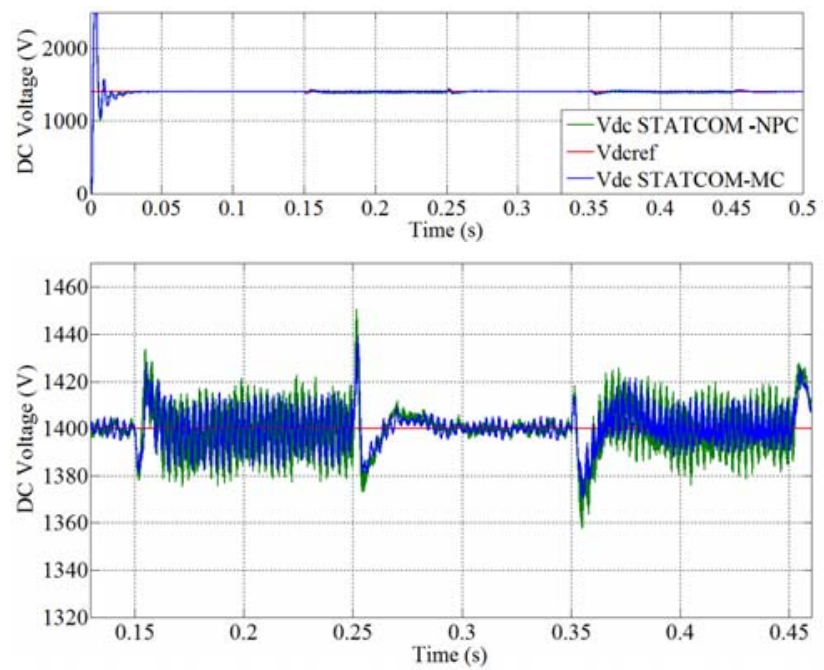

Fig. 15. Response curves of DC voltage 


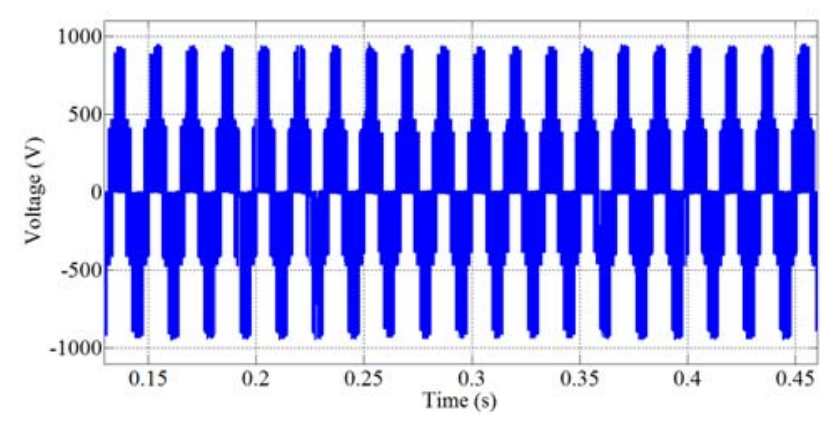

(a) Multi-cell converter

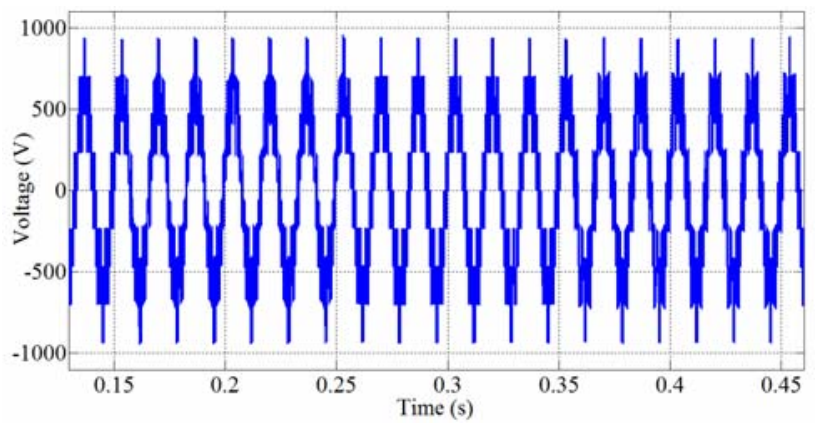

(b) NPC converter

Fig. 16. Output phase voltage of the STATCOM converter

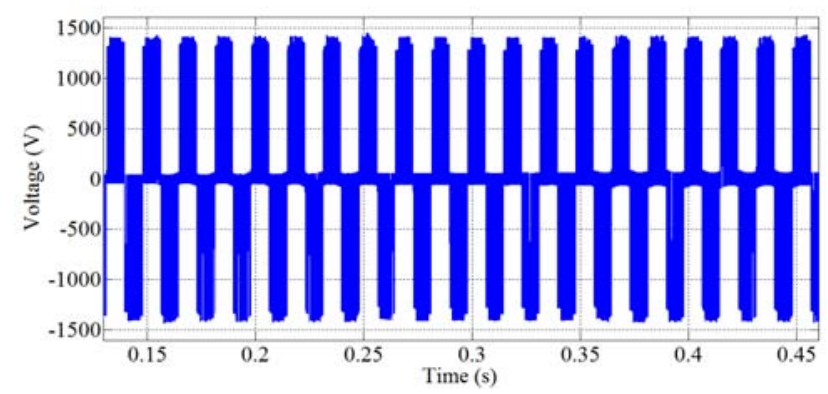

(a) Multi-cell converter

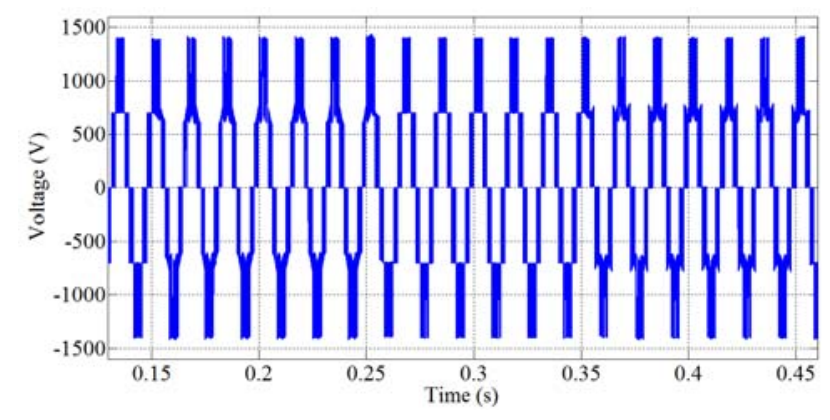

(b) NPC converter

Fig. 17. Output line voltage of the STATCOM converter

Case 2. A balanced three-phase inductive load is applied during the interval (0.25-0.35) s. Figures 18 and 19 shows the voltage drop caused by the inductive load at the period $t=(0.25-0.35) \mathrm{s}$. The STATCOM injects the reactive power (2.25 MVAR) into the line to maintain the voltage at the PCC connection point as shown in Fig. 20 and 21 in this case it operates in the capacitive mode as shown in Fig. 22. The reactive power exchange is achieved through the transformer leakage inductance which helps to smooth currents in advance of $90^{\circ}$ on the PCC common point voltages (see Fig. 23). Figure 24 shows the voltage across the dc capacitor.
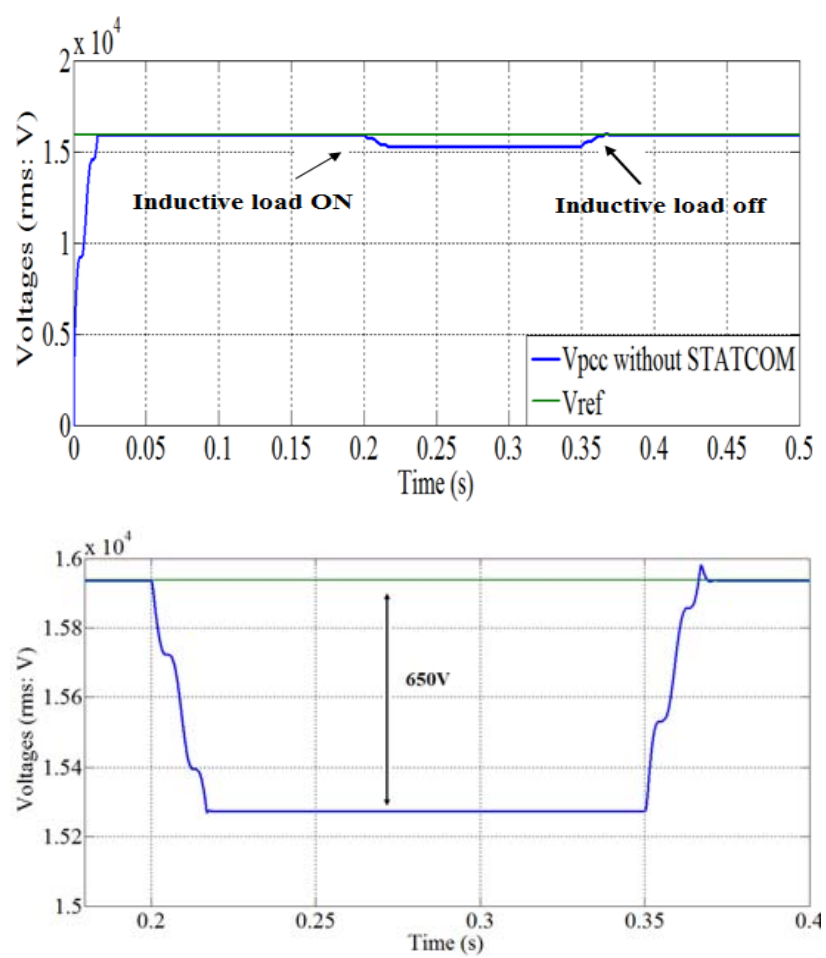

Fig. 18. Results of rms voltage phase to line at PCC without STATCOM

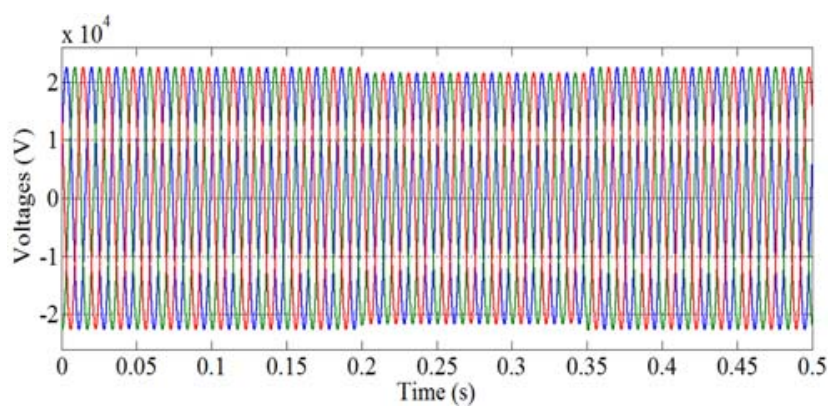

Fig. 19. Three-phase voltage $a b c$ at PCC without STATCOM
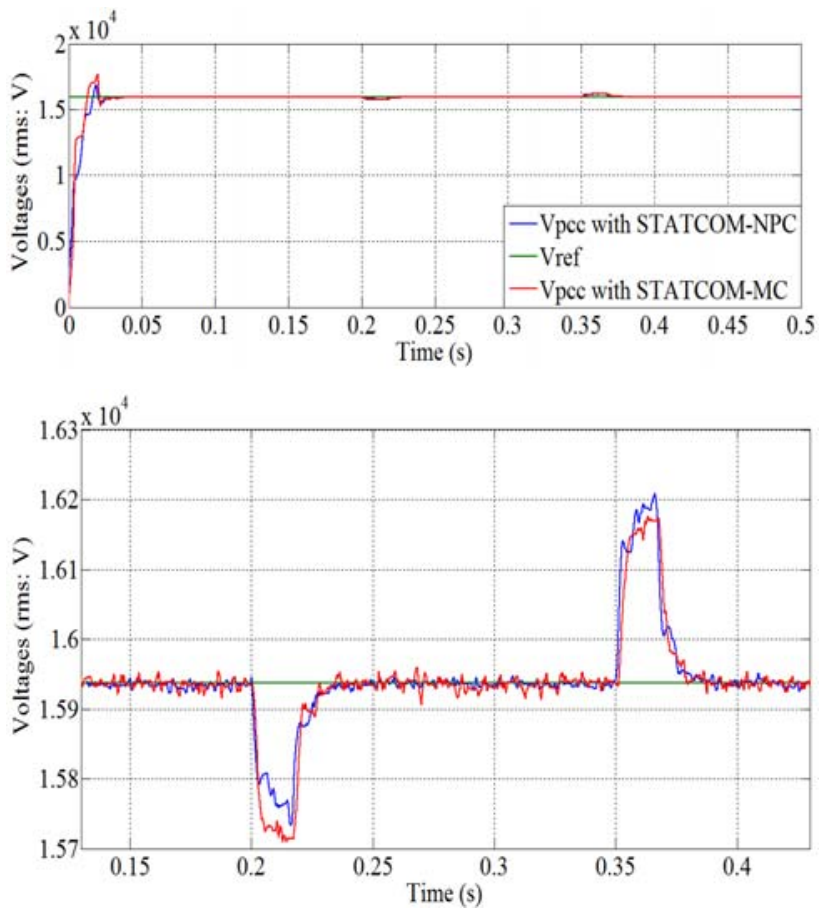

Fig. 20. Results of rms voltage phase at PCC with STATCOM 


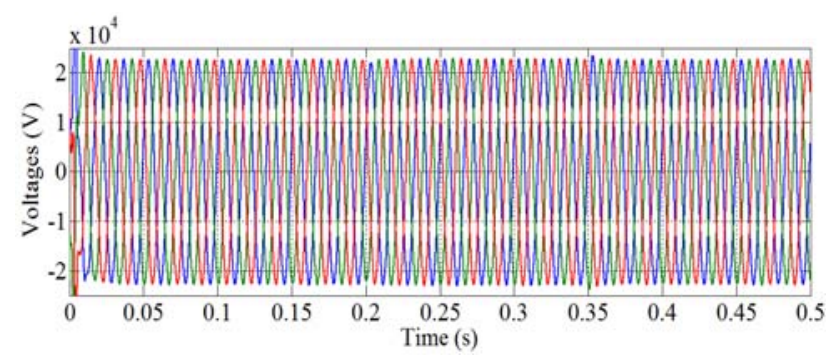

Fig. 21. Three-phase voltage $a b c$ at PCC with STATCOM

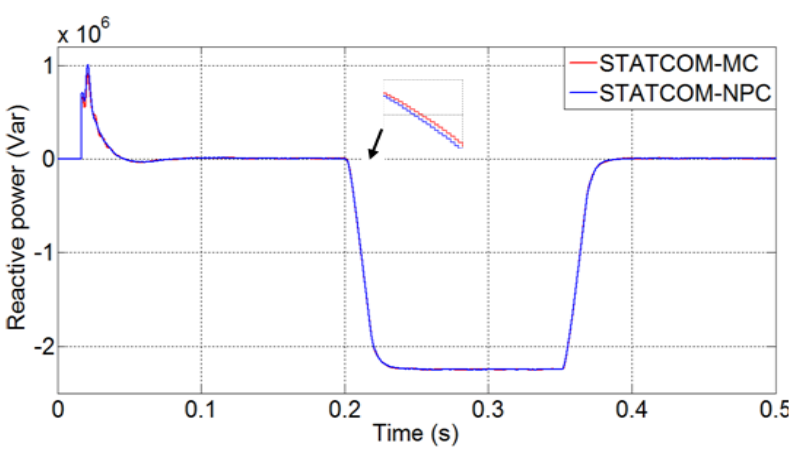

Fig. 22. Reactive power supplied and absorbed by STATCOM
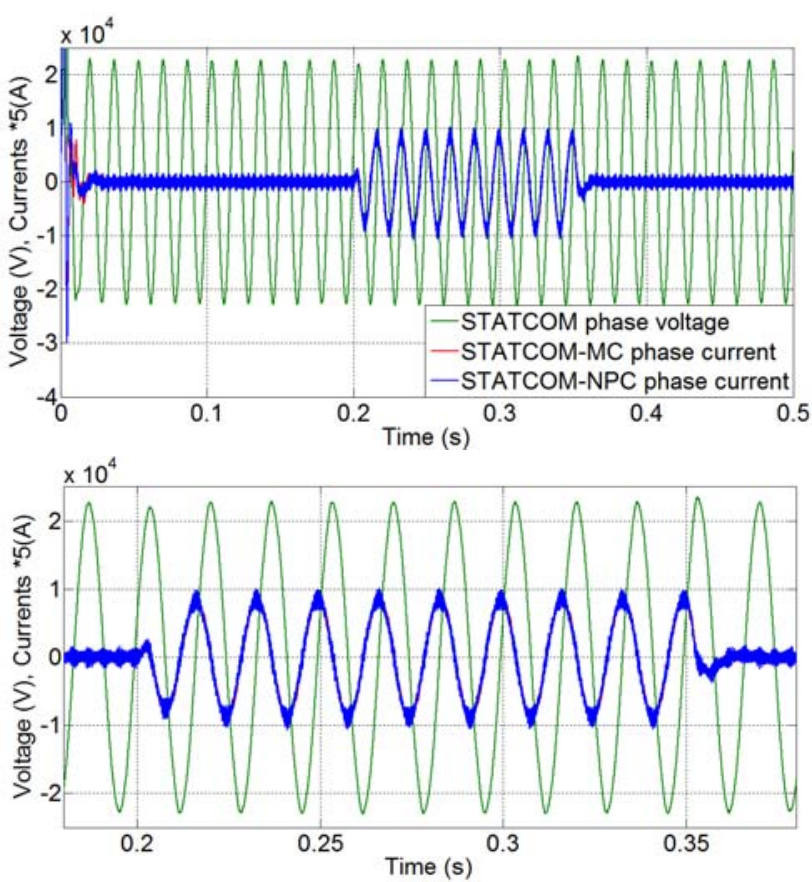

Fig. 23. Voltage and current of phase $a$ at the PCC
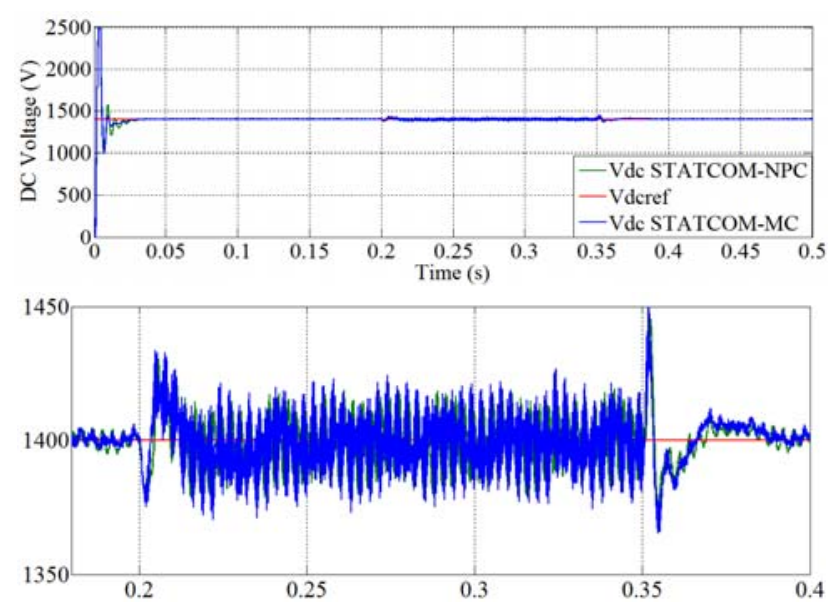

Fig. 24. Response curves of DC voltage
Case 3. A Fast Fourier Transform (FFT) analysis in MATLAB is used to conduct the harmonic analysis for multi-cells converter and multilevel NPC converter. It is summarized in Table 4. Using PWM technique, the THD $\%$ values of the three level NPC STATCOM and three level multi-cells STATCOM can be satisfied under IEEE Std. 519-1992 [22].

Table 4

Comparison of performance of MC-VSC and NPC-VSC

\begin{tabular}{|c|c|c|}
\hline \multirow{2}{*}{} & $\begin{array}{c}\text { Total Harmonic Distortion } \\
\text { THD (\%) Vabc at PCC }\end{array}$ & $\begin{array}{c}\text { Fundamental Vabc } \\
\text { at PCC }\end{array}$ \\
\cline { 2 - 3 } & \multicolumn{2}{|c|}{ Capacitive Mode } \\
\hline NPC-VSC & 1.12 & $2.54 \mathrm{e} 4$ \\
\hline MC-VSC & 1.46 & $2.54 \mathrm{e} 4$ \\
\hline & \multicolumn{2}{|c|}{ Floating Mode } \\
\hline NPC-VSC & 0.81 & $2.55 \mathrm{e} 4$ \\
\hline MC-VSC & 1.44 & $2.55 \mathrm{e} 4$ \\
\hline & \multicolumn{2}{|c|}{ Inductive Mode } \\
\hline NPC-VSC & 1 & $2.59 \mathrm{e} 4$ \\
\hline MC-VSC & 1.43 & $2.59 \mathrm{e} 4$ \\
\hline
\end{tabular}

Conclusion. This article presents a performance analysis of three-level NPC and multi-cell converters used in STATCOM applications for voltage regulation and reactive energy compensation in an electrical grid. The STATCOM model and the proposed control are implemented on SIMULINK / MATLAB to check steady state and dynamic performance. The simulation tests carried out have shown that the STATCOM with the proposed control is capable of supplying or absorbing the reactive energy to maintain the stable voltage at the common connection point (PCC) and whatever the type of disturbance (voltage drop or voltage dip). Finally, the two converters give almost identical output voltage values, so the values of the reactive powers are identical. But the voltage THD $(1.12 \%)$ is better for the NPC case. But against the point of view components used and the cost, the multi-cell converter is more interesting.

\section{REFERENCES}

1. Hingorani N.G, Gyugyi L. Understanding FACTS. Concepts and technology of Flexible AC Transmission Systems. IEEE Press, New York, 2000.

2. Kouro S., Malinowski M., Gopakumar K., Pou J., Franquelo L.G., Bin Wu., Rodriguez J., Pérez M.A., Leon J.I. Recent advances and industrial applications of multilevel converters. IEEE Transactions on Industrial Electronics, 2010, vol.57, no.8, pp. 2553-2580. doi: 10.1109/tie.2010.2049719.

3. Chetan E. Morkhade, Bhushan S. Rakhonde. Improvement in voltage profile using FACT device. International Journal of Scientific \& Engineering Research, 2013, vol.4, iss.6, pp. 27-32. 4. Huang Z., Shengzhen Y., Hongyan Y., Xingming F. A control method for SVPWM-based STATCOM using activereactive current decouple under $\mathrm{dq}$ coordinate system. International Conference and Exposition on Electrical and Power Engineering, EPE, Iasi, Romania, 2012, pp. 191-196. doi: 10.1109/icepe.2012.6463929.

5. Barik S.R, Nayak B., Dash S. A comparative analysis of three level VSC based multi-pulse STATCOM. International Journal of Engineering and Technology, 2014, vol.6, no.3, pp. $1550-1563$.

6. Liu X., Lv J., Gao G., Chen Z., Chen S. A novel STATCOM based on diode-clamped modular multilevel converters. IEEE Transactions on Power Electronics, 2017, vol.32, no.8, pp. 5964-5977. doi: 10.1109/tpel.2016.2616495. 
7. Malinowski M., Gopakumar K., Rodriguez J., Perez M.A. A survey on cascaded multilevel inverters. IEEE Transactions on Industrial Electronics, 2010, vol.57, no.7, pp. 2197-2206. doi: 10.1109/tie.2009.2030767.

8. Becker F. Contribution à la continuité de service des convertisseurs statiques multiniveaux. Phd de L'Université de Lorraine, 2017. (Fra).

9. Jones M., Satiawan I.N.W., Bodo N., Levi E. A dual fivephase space-vector modulation algorithm based on the decomposition method. IEEE Transactions on Industry Applications, 2012, vol.48, no.6, pp. 2110-2120. doi: 10.1109/tia.2012.2226422.

10. Baldés M. Etude d'un compensateur statique pour éoliennes à vitesse fixe à base de génératrice asynchrone à cage. Mémoire de Maitrise, Université du Québec, Canada, 2010. (Fra).

11. Berkoune K. Approche Mathématique pour la Modulation de Largeur d'Impulsion pour la conversion statique de l'energie électrique: Application aux onduleurs multiniveaux. Doctorat de l'université de Toulouse, France, 2016. (Fra).

12. Crappe M. Exploitation des Réseaux Electriques avec L'électronique de Puissance. Lavoisier, 2006. (Fra).

13. Hanafi S., Fellah M.K., Guebli A., Chiali E. Commande du convertisseur multicellulaire série ( 7 cellules) par SVM avec régulation des tensions flottantes. The 2nd International Conference on Power Electronics and Electrical Drives, Oran, Algeria, 2012. (Fra).

14. Defay F., Llor A.-M., Fadel M. A predictive control with flying capacitor balancing of a multicell active power filter. IEEE Transactions on Industrial Electronics, 2008, vol.55, no.9, pp. 3212-3220. doi: 10.1109/tie.2008.927989.

15. Defay F., Llor A.M., Fadel M. A direct predictive control of shunt active power filters using multicell converter. 2007 European Conference on Power Electronics and Applications, 2007, pp. 1-9. doi: 10.1109/epe.2007.4417411.

16. Darshan P., Vineetha R., Jil S., Pratik P. A comparative study of three phase 2-level VSI with 3-level and 5-level diode clamped multilevel inverter. International Journal of Emerging Technology and Advanced Engineering, 2014, vol.4, no.4, pp. 708-713.
17. Wanchai S. Design and analysis three phase three level diode-clamped grid connected inverter. Energy Procedia, 2016, vol.89, pp. 130-136. doi: 10.1016/j.egypro.2016.05.019.

18. Murugesan K., Muthu R. Modeling and simulation of DSTATCOM for voltage regulations. 2011 1st International Conference on Electrical Energy Systems, 2011. doi: 10.1109/icees.2011.5727975.

19. Giroux P., Sybille G, Le-Huy H. Modeling and simulation of a distribution STATCOM using Simulink's power system blockset. IECON'01. The 27th Annual Conference of the IEEE Industrial Electronics Society, 2001, pp. 990-994. doi: 10.1109/iecon.2001.975905.

20. Saha A., Ahmad S., Soma A.A., Chowdhury M.Z.A., Hossain A.A. Modelling and control of STATCOM to ensure stable power system operation. 2017 4th International Conference on Advances in Electrical Engineering (ICAEE), Sep. 2017, pp. 12-17. doi: 10.1109/icaee.2017.8255318.

21. Blažič B., Herman L., Božiček A., Papič I. Mathematical modeling and control algorithms of STATCOMs. Book chapter in Static Compensators (STATCOMs) in Power Systems, Dec. 2014, pp. 111-145. doi: 10.1007/978-981-287-281-4_4.

22. IEEE Standard 519-1992. IEEE Recommended Practices and Requirements for Harmonic Control in Electrical Power Systems. IEEE Inc., New York, 1992.

Received 24.06.2019

Soltane Belakehal ${ }^{1}$, Doctor of Electrotechnic, Associate

Professor,

Abed el hak Djellad ${ }^{1}$, Doctor of Electrotechnic, Associate

Professor,

Rachid Chenni ${ }^{1}$, Doctor of Electrotechnic, Professor,

${ }^{1}$ Department of Electrical Engineering,

University of Constantine 1,

Constantine, Algeria.

e-mail: bel_soltane@yahoo.fr, djellad.abedelhak@gmail.com, rachid.chenni@caramail.com

\section{How to cite this article:}

Belakehal S., Djellad A., Chenni R. Performance comparison of multicell series and NPC multilevel converters for a STATCOM. Electrical engineering \& electromechanics, 2019, no.5, pp. 60-67. doi: 10.20998/2074-272X.2019.5.10. 